\title{
Potential acting of a novice Achromobacter xylosoxidans strain as a plant growth- promoting factor
}

\author{
Abdel-Rahman H.M. ${ }^{1}$, Salem A. A. ${ }^{1}$, Mahmoud M.A.Moustafa ${ }^{2}$ and Hoda A.S. El-Garhy ${ }^{2}$ \\ ${ }^{1}$ Agric. Microbiol, Botany Dept., Fac. of Agric. at Moshtohor, Benha Univ. \\ ${ }^{2}$ Genetic Department, Fac. of Agric. at Moshtohor, Benha Univ. \\ Corresponding author: ahmed.nayl@fagr.bu.edu.eg
}

\begin{abstract}
Isolation of fifteen bacterial isolates were carried out from samples of a watering canal at Al HadadyDamrou, Kafr El-Sheikh Governorate, Egypt, $\left(31.3^{\circ} \mathrm{N} 30.93^{\circ} \mathrm{E}\right)$. Isolation was carried out on nitrogen free Ashby's medium. Screening process was achieved based on nitrogenase activity. The more potent bacterial isolate was selected for the subsequent experiments and was tested as a plant growth-promoting rhizobacteria (PGPR). Ultrastructural, cultural, biochemical characteristics and 16S rRNA partial sequence were used for identification and characterization the obtained isolate. The 16S rRNA sequencing results revealed that the nearest bacterial species to our isolate was Achromobacter xylosoxidans, with about $97 \%$ matching. Diazotrophic nature of this obtained isolate was confirmed by its ability to produce nitrogenase. Its ability to produce indole acetic acid, gibberellin and solubilize rock phosphate were confirmed through in vitro assay. Tomato inoculation with the obtained A. xylosoxidans under greenhouse conditions, significantly increased the vegetative growth, yield parameters as well as endogenous phytohormones content using with common free diazotrophic PGPR Azotobacter chroococcum as a reference isolate. Data revealed the importance of soil inoculation with the obtained isolate and its role in increasing soil enzymatic activity.
\end{abstract}

Keywords: Achromobacter xylosoxidans, PGPR, scanning and transmission electron microscopy.

\section{Introduction}

Bio-resources can be used as alternatives to chemical fertilizers for minimizing health hazards and environmental damage to achieve sustainable agricultural production. Improving both soil biochemical processes as well as plant performance has been done by the application of many rhizobacterial strains that have been proven useful as a major source of various bio-agents. PGPR act as biofertilizers, where biofertilizers are less expensive and more safely relative to chemical fertilizers (Abd El-Aal and Abd El-Rahman, 2014; Krishnaraj and Dahale, 2014). $\mathrm{N}_{2}$-fixing PGPR application as biofertilizer have been often potential and novel tools to both sustainability and productivity of agriculture (Sivasakthi et al., 2014). I addition to nitrogen fixation, PGPR may also have other plant-growthpromoting activities such as helping in phosphorus solubilization process which facilitate mineral uptake and producing phytohormones, also it has an important role in stimulating disease-resistance mechanisms (Dobbelaere et al., 2003; Vacheron et. al. 2013). The solubility of some nutrients such as $P$, $\mathrm{Fe}, \mathrm{Zn}, \mathrm{Mn}$ and $\mathrm{Cu}$ have been positively influenced by the reduction of soil $\mathrm{pH}$ as a result of the application of PGPR which increases nutrient uptake by plants (Abd El-Aal and Abd El-Rahman, 2014).

Identifying of Achromobacter species based on traditional phenotypic profile- analyses, particularly A. xylosoxidans, have been demonstrated to be inadequate to differentiate them from other similar Gram-negative, aerobic and non-fermenting species
(Wayne et al. 1987; Wittmann et al.2014). While using biomarker genes such as 16SrRNA gene for genotypic- analysis, has been recommended as the paramount reference standard for taxonomic reference, microbial phylogenetic relationships, and identification of isolates in many laboratories (Wayne et al. 1987; Spilker et al. 2013; Gomila et al. 2014).

Production of different phytohormones has been taken place in several PGPR belonging to Achromobacter xylosoxidans, (Abd El-Azeem, 2007; Vacheron et. al. 2013). More of fixed nitrogen appears to be provided by A. xylosoxidans as a diazotrophic endophytic bacterium when compared to rhizospheric bacteria where the plants interior is more suitable position for nitrogen fixation in view of low partial oxygen pressure (pO2) leading to direct accessibility of the fixed nitrogen to the plants (Prabhat and Kumar 2009). Therefore, this experiment was designed to isolate new friendly diazotrophic bacterial isolates using traditional, biochemical, ultrastructural (SEM, TEM) and 16S rRNA gene sequence methods. Studying the effect of the obtained isolate as a promising PGPR on different plant growth parameters under greenhouse condition has been studied using tomato (Lycopersicon esculentum var. commune).

\section{Materials and methods}

\section{Samples collection}

Water samples were collected from the agricultural canal at Al-Hadady, Damaroa, Kafr El- 
Sheikh Governorate, $\left(31.3^{\circ} \mathrm{N} 30.93^{\circ} \mathrm{E}\right)$. Samples of water were transferred in sterile plastic bags and delivered to the laboratory (at Botany Department, Faculty of Agriculture at Moshtohor, Benha University) within four hours after their collection under aseptic conditions.

\section{Isolation and screening of bacterial isolates}

Isolation was performed using Ashby's medium by serial dilution and spread plate method as described earlier by Aneja, (2003). Bacterial isolates were screened according to nitrogenase activity. Pure isolates on tryptic soya agar slants were maintained at $4^{\circ} \mathrm{C}$. Shape of the more potent bacterial isolate was examined under a high power magnifying lens using a light microscope by the Gram stain reaction, sporulation, motility and flagella staining procedures by methods described by Bertrand et al. (2001). The cultural characteristics were recorded according to the method described by Ding et al., (2005).

\section{Scanning and Transmission Electron Microscopy (SEM)}

Bacterial isolate was fixed in $2.5 \%$ glutaraldehyde in $0.1 \mathrm{M}$ phosphate buffer, $\mathrm{pH} 7.2$, for $2 \mathrm{~h}$ at room temperature and washed in the same buffer. The sapphire disks were peeled away from the Epon before thin sectioning, but the biological material remained embedded in the plastic resin and later was sectioned. For planktonic samples, the copper tubes required some trimming so that no copper came into contact with the knife face during sectioning. Sections were ridden on Formvar- and carbon-coated 200-mesh copper grids. To improve contrast, sections were post-stained in $2 \%$ (wt/vol) uranyl acetate. Electron microscopy was performed on a Philips CM10 transmission electron microscope operating at $80 \mathrm{kV}$ under standard operating conditions (Hunter and Beveridge 2005). Photomicrographs were then carried out with a JOEL1010 model at the Regional Center for Mycology and Biotechnology (RCMB), Al-Azhar University.

\section{API ${ }^{\circledR} 20$ method}

The bacterial isolate was biochemically characterized by The API ${ }^{\circledR} 20$ E system strips that consist of 20 micro-tubes containing dehydrated substrates. The conventional tests were inoculated with a saline bacterial suspension which reconstitutes the media. During incubation, metabolism produces color changes that are either spontaneous or revealed by the addition of reagents. The reactions were read according to the reading table included with the API kit and the identification is obtained by referring to the analytical profile index or using the identification software.

\section{Antibiotics susceptibility test}

Susceptibility test of more potent isolate was performed by the disk diffusion method and interpreted according to Matuschek et al. 2014. The following antibiotics were tested: $\beta$-lactams (cefotaxime, ceftazidime, oxacillin, meropenem, aztreonam, amoxicillin+clayulanic acid; augmentin; imipenem, trazobactam and ampicillin), aminoglycosides (amikacin and gentamicin), glycopeptide (vancomycin), cephalosporin (cephradine,cefodizime, cefoxitin, cefixime, cefadroxil and cefepime), oxazolidinone (linezolid), fluoroquinolone (ofloxacin and levofloxacin), and ansamycins (rifamycin).

\section{PCR reaction}

For PCR amplifications, the bacterial genomic DNA was extracted from inoculated LB broth media with bacterial isolate and incubated overnight at $37^{\circ} \mathrm{C}$ with shaking. PCR analysis was performed using $16 S$ rRNA gene according to (Jiang et al. 2006). The primers used were universal $27 \mathrm{~F}\left(5^{\prime}\right.$ AGAGTTTGGATCMTGGCTCAG-3') and 1492R (5'-CGGTTACCTTGTTACGACTT-3'). The PCR reaction was selectively amplified in $50 \mu \mathrm{l}$ reaction mixtures composed of $0.4 \mu \mathrm{M}$ of each primer, 400 $\mu \mathrm{M}$ of dNTP mix, $5 \mu \mathrm{l}$ of $10 \mathrm{x}$ PCR reaction buffer, 2 $\mathrm{mM} \mathrm{MgCl}_{2}, 2.5$ units from TAKARA TaqDNA polymerase (Cat. \#:R001AM) and $1 \mu \mathrm{g}$ DNA. The amplification conditions on a Master cycler (Eppendorf) were as follows: initial denaturation step at $95^{\circ} \mathrm{C}$ for $3 \mathrm{~min}, 35$ cycles of amplification $\left(95^{\circ} \mathrm{C}\right.$ for $50 \mathrm{sec}, 52^{\circ} \mathrm{C}$ for $1 \mathrm{~min}$ and $72^{\circ} \mathrm{C}$ for $1 \mathrm{~min}$ ), and followed by a final extension at $72^{\circ} \mathrm{C}$ for $10 \mathrm{~min}$. Amplified PCR product was analyzed by electrophoresis on $1.2 \%$ agarose gel stained with Ethidium bromide using GeneRuler ${ }^{\mathrm{TM}} 1 \mathrm{~kb}$ DNA ladder (Cat. \#: SM0313), then visualized under UV Transilluminator.

\section{Cloning and sequencing}

The expected DNA band, almost 1500 bp,was eluted from agarose gel and purified according to manufactures of QIA quick Gel Extraction Kit (Cat.\#: 28704). The competent cells from top 10 strain ware prepared and transformed according to (Inoue et al. 1990). The white colonies were picked up from LB/Amp/Xgal plates and inoculated on LB/Amp broth media. Then, it incubated overnight at $33^{\circ} \mathrm{C}$ with shaking for stabilizing the plasmid inside the transformed cells. The plasmid was isolated according to the alkaline method (Birnboim and Doly 1979). The purified plasmids were analyzed by electrophoresis on $1.2 \%$ agarose gel using GeneRuler $^{\mathrm{TM}} 1 \mathrm{~Kb}$ DNA Ladder (Cat. \#: SM0313) to confirm the recombinant plasmids. The recombinant plasmids were sequenced by-Macrogen Company (South Korea).

\section{Phylogenetic analysis}

The obtained sequence for $16 S$ rRNA gene was analyzed by VecScreen tool for vector contamination (http://www.ncbi.nlm.nih.gov/tools/vecscreen/). 
Also, NEbcuter V2.0 was used to create a restriction map and to identify the GC content of the obtained sequence (Vincze et al. 2003, http://nc2.neb.com/NEBcutter2/). ORF finder software was used to obtain possible ORFs of the obtained sequence. Also, Jalview software was used to show SNPs and consensus resulted from the alignment of our bacterial isolate obtained sequence and the nearest bacterial strain in NCBI database (http://www.jalview.org/). Construction of the phylogenetic tree was done by using Clustal Omega and MEGA6 software.

\section{Plant growth promoting features of $A$. xylosoxidans}

Nitrogenase activity was measured as a guide for nitrogen fixation using the acetylene reduction technique given by Diloworth (1970). $A$. xylosoxidans isolate was screened for its phosphate solubilizing ability on Pikovskaya's (PVK) media, according to Nguyen et al. (1992). Quantitative assessment of phosphate solubilization was determined on the National Botanical Research Institute's Phosphate (NBRIP) growth and broth media (Nautiyal, 1999).

The ability of A. xylosoxidans isolate to produce indole acetic acid (IAA) and gibberellins (GA3) was qualitatively determined on Yeast Extract Mannitol broth medium according to the method described by Sarwart et al.(1992) and Pandya and Desai (2014), respectively.

\section{Evaluation of tomato inoculation with $A$. xylosoxidans}

Plant growth-promoting potential of $A$. xylosoxidans was evaluated and compared with common free diazotrophic PGPR reference strain named Azotobacter chroococcum EMCCN1458 that obtained from Microbiological Resources Centre (MIRCEN) Cairo, Egypt

Pots experiment was carried out in a greenhouse, Faculty of Agriculture, Benha University -Qalyubia Governorate, Egypt, during March to May 2015. Plastic pots, $20 \mathrm{~cm}$ in diameter and $27.5 \mathrm{~cm}$ in depth, were filled with a mix of $20 \mathrm{~kg}$ soil (clay soil, $\mathrm{pH}$ 8.03 , organic matter $3.1 \%$, bulk density $1.36 \mathrm{~g} \mathrm{~cm}^{-3}$, field capacity $51.1 \%$, wilting Point $17.05 \%$ ) and $10 \mathrm{~g}$ compost (cattle manure and herbal plants residues (50: 50) are: $\mathrm{pH}$ 7.6, Electrical conductivity (EC) 3.1 $\mathrm{dS} \mathrm{m} \mathrm{m}^{-1}$, total organic matter values $32.7 \%$, total-N $1.21 \%$, total-P $0.91 \%$ and the porosity $62.67 \%$ ).

Prior to transplantation, tomato seedlings (c.v. Super Strain B) were obtained from a special nursery in Qaha city and divided into three groups. The first and the second were soaked by dipping the root system in mixture of $10 \%$ Arabic gum as an adhesive for inocula of either $A$. xylosoxidans or $A$. chroococcum EMCCN1458 $\left(7 \times 10^{6}\right)$ cell suspension for 30 minutes before transplanting. The third group was not treated with bioinoculants as a control.
Tomato were transplanted (2 seedlings/pot) and arranged in a randomized complete plot design with one factor and ten replicates. Tomato plants were weakly irrigated and the boost dose of PGPR strains were added at 30 and 50 days after transplanting (DAT). Chemical fertilizers were supplemented to all treatments with $1 / 4$ of the recommended dose $(50 \mathrm{~kg}$ $\mathrm{Nfed}^{-1}$ as ammonium sulfate $(20.5 \% \mathrm{~N}), 25 \mathrm{~kg}$ $\mathrm{P}_{2} \mathrm{O}_{5} \mathrm{fed}^{-1}$ as super phosphate $\left(15.5 \% \mathrm{P}_{2} \mathrm{O}_{5}\right)$ and $40 \mathrm{~kg}$

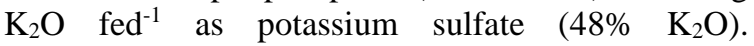
Dehydrogenase, phosphatase and nitrogenase activities were determined at 30, 60 and 90 DAP. At the flowering stage (60 DAT), plant samples were randomly collected to measure different growth parameters and phytohormones content. A total number of fruits/ plant was recorded after 90 DAT.

\section{Measurements of microbial enzymatic activity}

The microbial enzymatic activities were determined in rhizosphere at initial, 15, 30 and 60 DAT. The activities of dehydrogenase (DH) and alkaline phosphatase (Alp) were measured using spectrophotometer (SCO-Tech, SPUV-19, Germany) at 464 and $400 \mathrm{~nm}$, respectively, by the method of Schinner, et al. (1996). While nitrogenase $\left(\mathrm{N}_{2}\right.$-ase $)$ activity was measured as previously mentioned with some modification by Okafor and MacRae (1973).

\section{Morphological, endogenous phytohormones and yield characteristics}

Ten plants from each treatment were randomly taken to evaluate vegetative growth parameters, stem length $(\mathrm{cm})$, a number of branches/plant, shoot dry weight $(\mathrm{g})$, root size $\left(\mathrm{cm}^{3}\right)$ and flowers no./plant. A total number of fruits/ plant was recorded for each treatment as well as fruits setting percentage was calculated. Endogenous Phytohormones (IAA, GA3 and abscisic acid) were quantitatively determined in tomato shoots at 60 DAT using high-performance liquid chromatography (HPLC; YL9100 HPLC System, Korea) according to the method of Koshioka, et al., (1983). Determination of cytokinin was determined by HPLC according to Nicander, $\boldsymbol{e t}$ al., (1993).

\section{Statistical analysis}

Data were statistically analyzed according to the procedures outlined by Gomez and Gomez (1984). For comparison between means, Duncan's multiple range test was used (Duncan, 1955). Means followed by the same alphabetical letters were not significantly different at $5 \%$ level of significance.

\section{Results}

\section{Isolation and screening of bacterial isolates}

Fifteen different bacterial isolates were detected on ashby's medium. Bacterial isolates were screened based on nitrogenase activity (Fig 1) and the more 
potent bacterial isolate (Is1) was selected for the subsequent experiments.

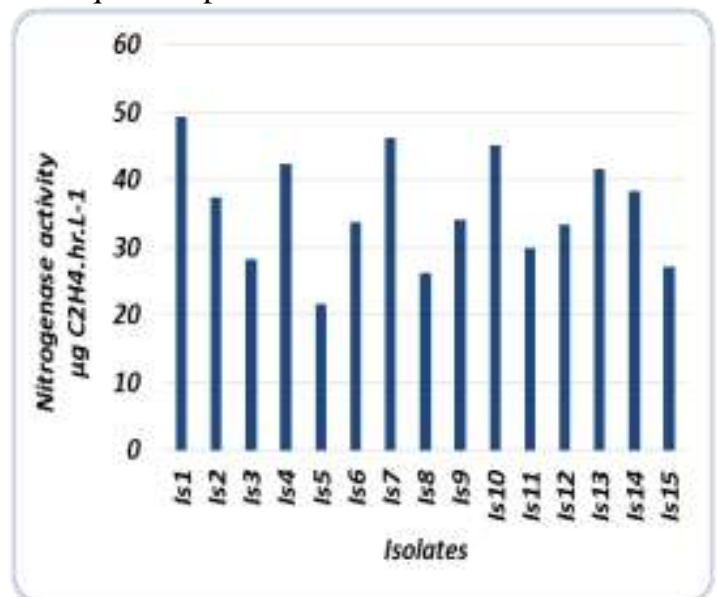

Fig1. Screening of bacterial isolates according to nitrogenase activity.

\section{Morphological characters of the more potent bacterial isolate}

After $48 \mathrm{~h}$ of incubation on nitrogen free Ashby's medium, at $35^{\circ} \mathrm{C}$, the colonies ranged in size from 0.5 to $2.25 \mathrm{~mm}$ in diameter, had become opaque and mucoid. Continued incubation resulted in a colony with diameter from $3.0-4.8 \mathrm{~mm}$. After incubation at $35^{\circ} \mathrm{C}$ for $12 \mathrm{~h}$ 0n the tryptic soya broth culture exhibited a barely visible turbidity that after an additional $12 \mathrm{~h}$, it increased to approximately 2.0 $\times 10^{9} \mathrm{cfu} \mathrm{ml}^{-1}$. The growth was uniformly distributed throughout the broth. A small amount of sediment was produced by the isolate that rose upward by rotation.

Continued incubation led to turbidity increase near the surface and the formation of a slimy pellicle. Regarding, microscopic morphology, the obtained bacterial isolate was straight rods, 0.6-1.2 $\mu \mathrm{m}$ with rounded ends (Table 1). It was Gram negative, single and diploid, non-spore forming and motile with peritrichously-arranged flagella (Fig. 2).

Table1. Morphological and cultural characteristics of bacterial isolate.

\begin{tabular}{|c|c|}
\hline & Characteristics \\
\hline Shape & $\begin{array}{l}\text { Straight rods, } 0.6-1.2 \mu \mathrm{m} \\
\text { with rounded ends }\end{array}$ \\
\hline Gram stain & Gram negative \\
\hline Spore formation & Nonspore forming. \\
\hline Motility & $\begin{array}{l}\text { Motile by peritrichous } \\
\text { flagella }\end{array}$ \\
\hline Respiration & aerobic \\
\hline \multicolumn{2}{|l|}{ Colonies appearance } \\
\hline Color & Nonpigment \\
\hline Size & 0.5 to $2.25 \mathrm{~mm}$ in diameter \\
\hline Opacity & Opaque and mucoid. \\
\hline $\begin{array}{l}\text { Grow on Ashby's } \\
\text { medium }\end{array}$ & Positive \\
\hline
\end{tabular}

Electron micrographs (SEM and TEM) images revealed the accumulation of extracellular material surrounding one pole of the Achromobacter isolate cells and forming a polar cap as shown in (Fig.2 and 3 ). These accumulations add irregular contours so that many of the cells had a coryneform appearance. On Gram stain, curved (solid arrowhead) and hooked-end (arrow) forms were also presented.

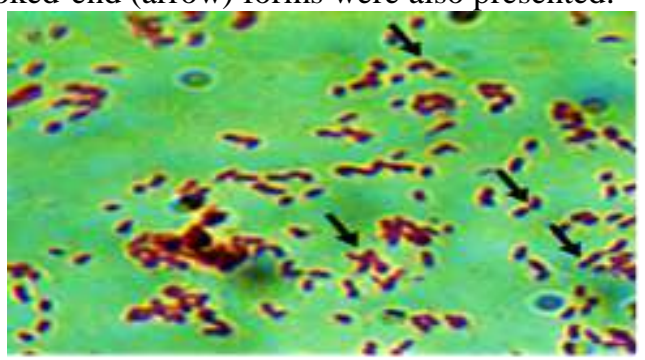

Fig 2. Photogram showing gram stain appearance of Achromobacter isolate. Many of the cells have a coryneform appearance, curved (solid arrow- head) and hooked-end (arrow) forms are also present.

\section{Biochemical characteristics}

The bacterial isolate grew on nitrogen free Ashby's medium, and showed obligatory aerobic features. Based on API system (Table 2), it was oxidase positive and gelatinase negative. It utilized glucose as sole carbon source and produced acid derived from glucose, mannitol, inositol, sorbitol, rhamnose, saccharose, melibiose, amygdalin, arabinose and xylose. Data showed that the obtained isolate was capable of using denitrification as a respiratory process with nitrate electron acceptor.

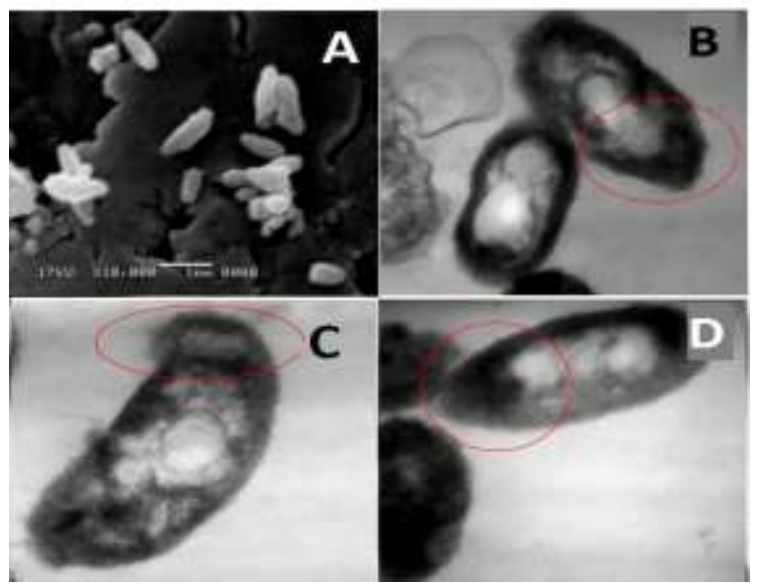

Fig 3. Electrophotogram showing ultrastructure images of Achromobacter sp.: A: Scanning electron microscopy image (SEM). B, C and D: transmission electron microscopy images (TEM).

\section{Antibiotics susceptibility test}

Antibiotic susceptibility patterns of the Achromobacter. Isolate was demonstrated a susceptibility profile characteristic (Fig 4). The isolate was resistant to ceftazidime, amoxicillin+clayulanic acid (augmentin), linezolid and rifamycin. It was categorized as intermediate resistant to cefotaxime, oxacillin, meropenem, trazobactam, ampicillin, cefodizime, cefoxitin, cefixime, cefadroxil, cefepime and ofloxacin. It remained susceptible to aztreonam, imipenem, 
amikacin, centamicin, vancomycin, levofloxacin and trimethoprim/sulfamethoxazole (Bactrim).

DNA and phylogenetic analysis
The obtained PCR amplified fragment for $16 \mathrm{~S}$ rRNA gene was $\approx 1500$ bp (Fig.4). Analysis of the obtained sequence via Vecscreen database showed no contamination with vector sequence.

Table 2. The API ${ }^{\circledR} 20 \mathrm{E}$ strip results.

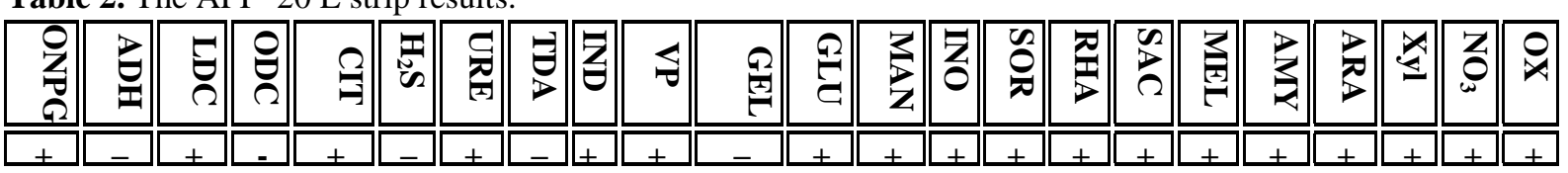

ONPG: $\beta$-galactosidase (Ortho nitrophenyl-ßd- Galactopyranosidase),ADH: Arginine dihydrolase, LDC: Lysine decarboxylase, ODC: Ornithine decarboxylase, CIT: citrate utilization, $\mathbf{H}_{2} \mathrm{~S}: \mathrm{H}_{2} \mathrm{~S}$ production, URE: urease, TDA: Tryptophane deaminase, IND: indole production, VP: acetoin production (Voges Proskauer), GEL: gelatinase, GLU: fermentation of glucose, MAN: fermentation of mannitol, INO: fermentation of inositol, SOR: fermentation of sorbitol, RHA: fermentation of rhamnose, SAC: fermentation of saccharose, MEL: fermentation of melibiose, AMY: fermentation of amygdalin, ARA: fermentation of arabinose, Xyl: fermentation of xylose, $\mathbf{N O}_{3}$ : nitrous reduction, OX: cytochrome-oxidase. (+) refers to developed color; (-) refers to colorless.

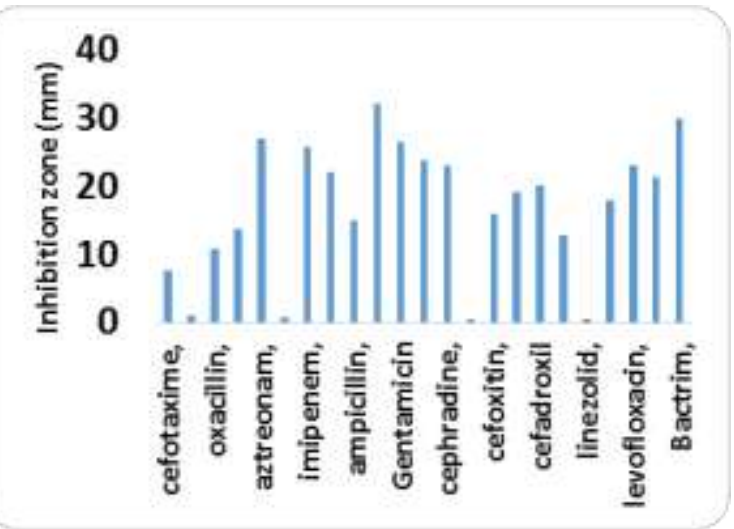

Fig. 4. Antibiograms of Achromobacter isolate by disk diffusion method.

The FASTA homology showed that the $16 \mathrm{~S}$ rRNA gene sequence of the current isolate had $97 \%$ nucleotide similarity with that of Achromobacter xylosoxidans strain recorded in NCBI database (ACC. no. AJ880396.1).This result was confirmed by the phylogenetic position of the obtained isolate, forming polyphyletic clade with A. xylosoxidans, but with an obvious phylogenetic distance (Fig. 6). Also, the restriction Map of the obtained 16S rRNA partial sequence was done (data not shown). By calculating pairwise alignment analysis, data exhibited 14 SNPs between the sequence of the obtained isolate and the nearest registered bacterial strain in NCBI database, A. xylosoxidans (AJ880396.1), for 16S rRNA gene (Fig.7).

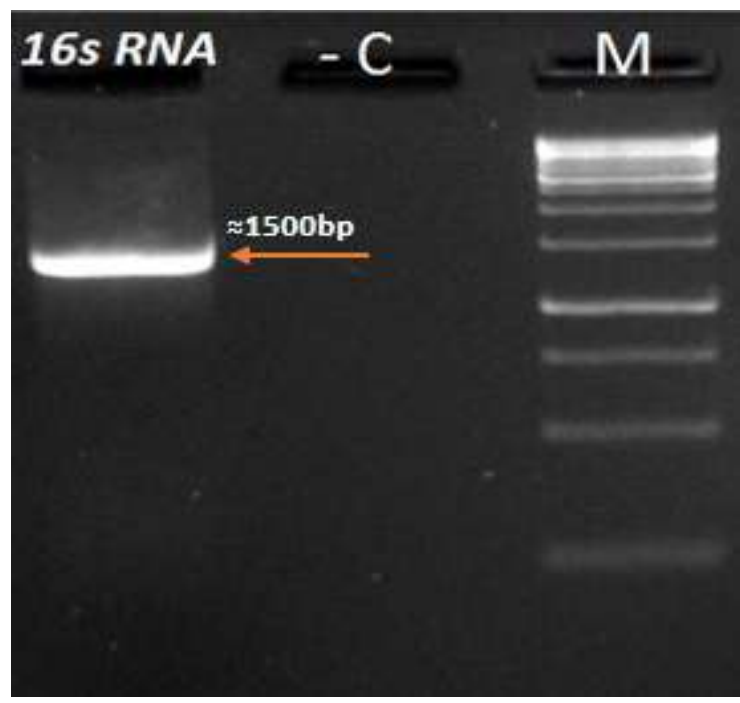

Fig 5. PCR products for 16s RNA partial-length gene $(1500 \mathrm{bp})$ of the obtained diazotrophic bacterial isolate. $-\mathrm{C}$, negative control, no DNA sample. $\mathrm{M}$ refers to GeneRulerTM 1kb DNA ladder (Cat. \#: SM0313).

\section{Plant growth promoting features of $A$. xylosoxidans in vitro}

Under laboratory condition, A. xylosoxidans was bio-assayed for its growth promoting potentiality through nitrogenase activity and phytohormones production such as auxins and gibberellins (Table 3).

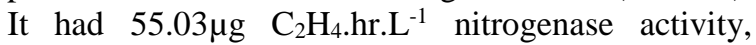
indicating its ability to fix atmospheric $\mathrm{N}_{2}$. It also produced $50.8 \mu \mathrm{g} . \mathrm{ml}^{-1}$ of IAA and $10.35 \mu \mathrm{g}$. ml ${ }^{-1}$ of GA3. Moreover, it was able to solubilize rock phosphate on PVK agar medium, and it showed $104 \%$ phosphate solubilization efficiency. The quantitative assessment of phosphate solubilization on NBRIP broth medium was $23.7 \mu \mathrm{g} \cdot \mathrm{ml}^{-1}$. 


\section{(B)}

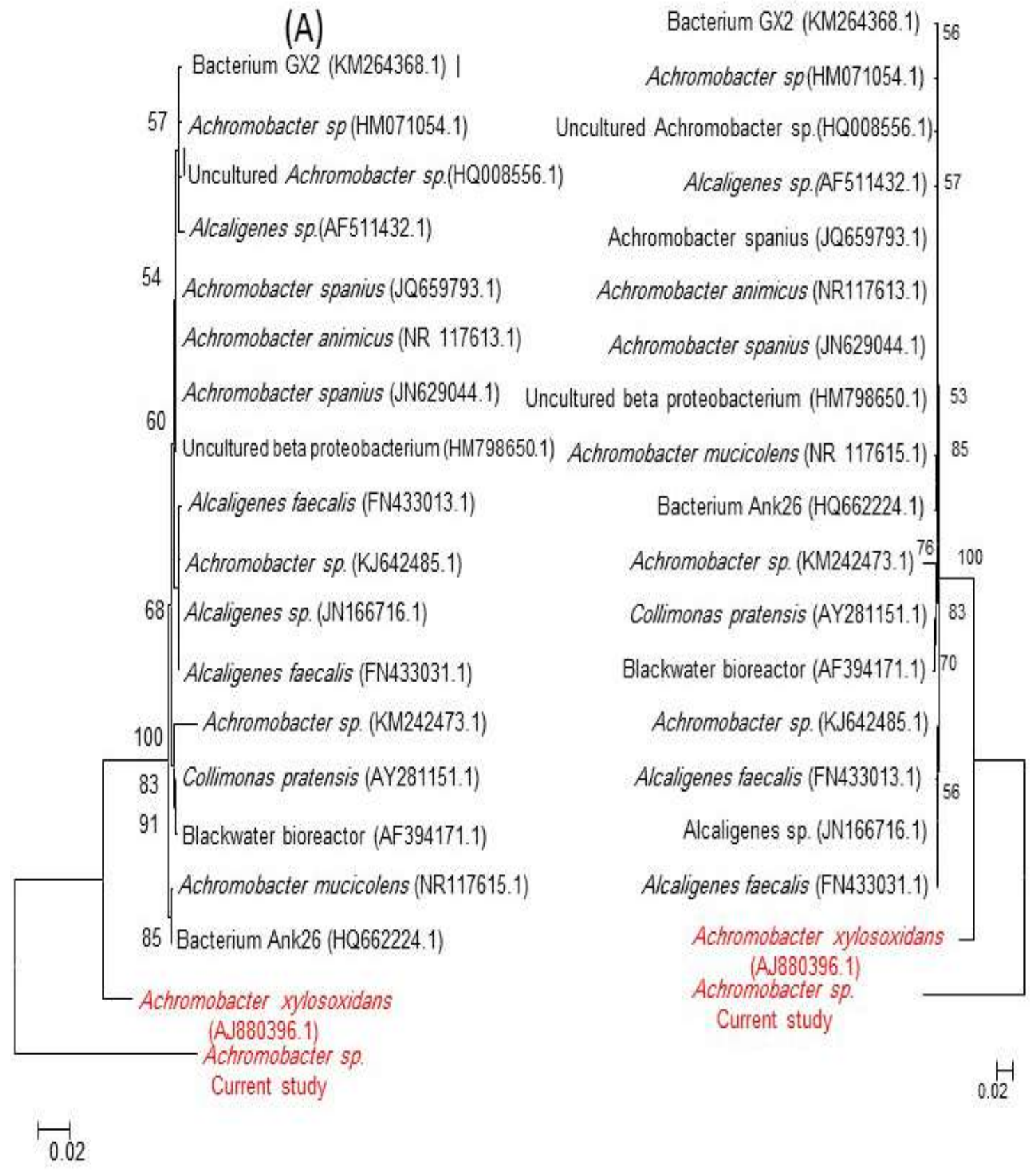

Fig 6. Phylogenetic trees recovered from maximum likelihood (a) and neighbor joining (b) analyses of the $16 \mathrm{~S}$ rRNA gene Partial sequences. The trees show the phylogenetic position of recovered Achromobacter species within the phylogenetic branches of the family Alcaligenaceae. Average Bootstrap values, of compared algorithms, are indicated at the branch roots. The bar represents 0.02 changes per nucleotide. Accession numbers of database extracted sequences are in brackets. 


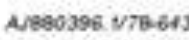
carrentuhud or to 660

Comentivas

A.4e0306 1720-43 comentesisytsed

Comeness

A 1900996 1/78-643 earencietufy t-560

Coniemas

A.940306 978-643

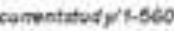

Cemeneys

Avebos96 $1 / 78-643$ comentatud proseo

Comentas

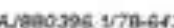
coarentatudy's-6ed

Cemeness

Aveaos96. n7e-64d cuarentatod ot t- 560

Concentiat

Nieso 396 9 978-64: conentetudy r.6e0

Cemenges

Comentus

Nee0094. $1 / 78.643$ conentatus p'toes

Cenanness coveosec $1 / 78-643$

Conemons

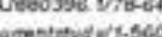

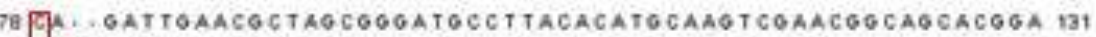

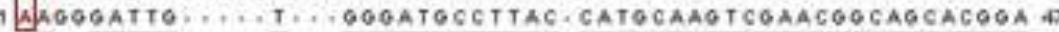

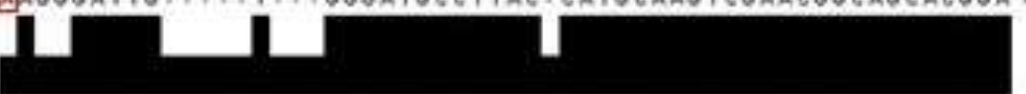

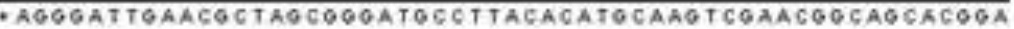

IS CTTCOOTCTOOTOOCOAOTOOCOAACOOOTOAOTAATOTATC.OOAMCOTOCCTAP TBO Al CTTCOOTCTOOTOOCOAOTOOCOAACOOOTOAOTAATOTATCCOOADEOTOCCTAII 103

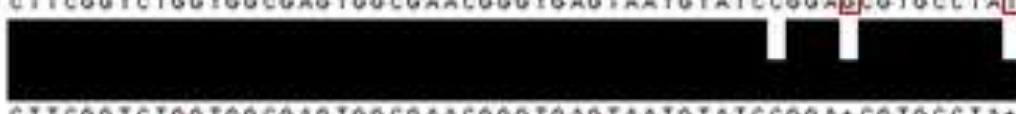

CTTCOOTCTOOTOOCOAOTOOCOAACOOOTOAOTAATOTATCCOOA+COTOCCTA.

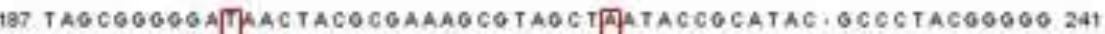
10A TAOCOGGOOAGLACTACOCGAAAG CQTAOCTCATACCOCATACAOCECTACQGOGO

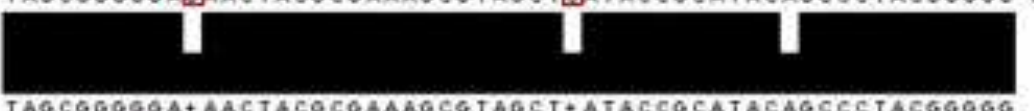

TAGCQGOGOATAACTACOCOAAAOCGTAOCT +ATAGCOCATACAGCCSTACGQOGQ

242 AAAOCAOPPOATCOTAAOACCTTGCACTATTAOAOCOOCCOATATCOOATTAOCTA $29 \%$ 160 AAAOCA. TOOATCOTAAOACCTTOCACTATTAOAOCOOCCOATATCOOATTAOCTA 214

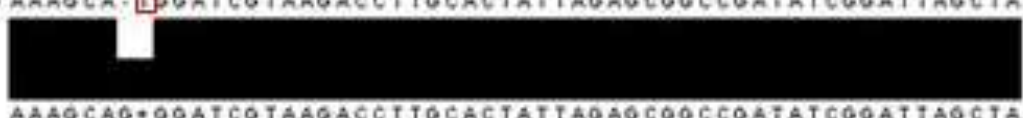

AAAOCAOPOOATCOTAAGACOTFOCACTATTAOAOCOOCCOATATCOOATTAOCTA

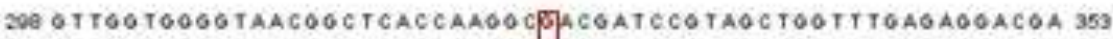
216 OTTO6 T6060 TAACO6CTCACCAAOOCLACOATCCOTAOCTOOTTTGAOAOOACOA. 270

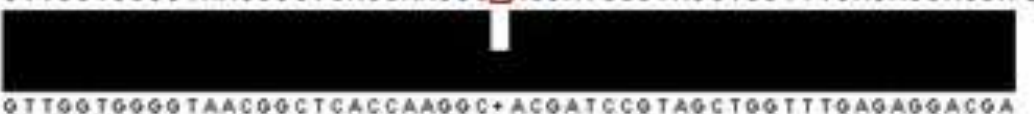

OTTOOTGQQOTAACOOGTCACCAAOOC+ACOATCCOTAOCTOQTTTQAQAGQACGA

WA CCAOCCACACTOQGACTOAOACACOOCCCAFACTCCTACOOGAOOCAOCAOTOOOO ADQ 271 CCAOCCACACTOOOACTOAOACACOOCCCAUACTCCTACOOOAOOCAOCAOTOOOO 328

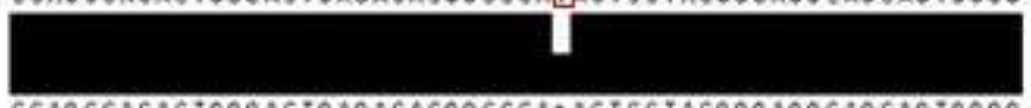

CCAOCCACACTOOOACTOAOACACOOCCCANACTCCTACOOOAOOCAOCACTOOOO

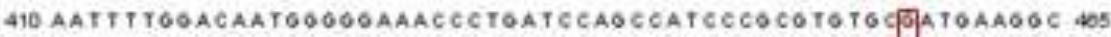
227 AATTTTOOACAATOOOO6AAACCCTOATCCAOCCATCCCOCOTOTOCUATOAAOOC 382

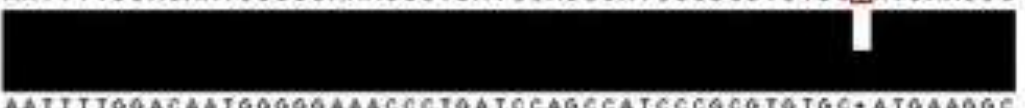

AATTTTOOACAAT OOQOOAAACCCTOATOCAGCCATCCCOCOTOTGOAATQAAG

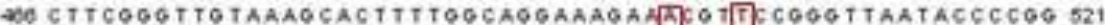

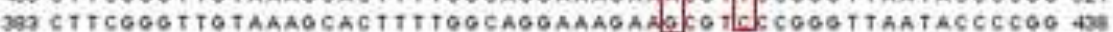

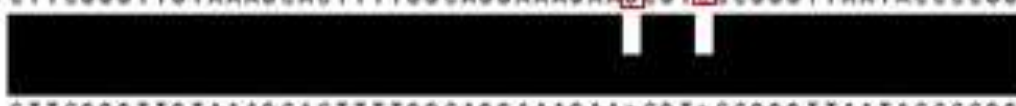

CTTCOOOTTOTAAAOCACTTTTOOCAOGAAAOAAOCOTHCCOOOTTAATACCCCOO

622 OAAACTOACOOTACCTOCAOAATAAOCACCOOCTAACTACOTOCCAOCAOCCOCOO 577 430 OA.A.ACTOACOOTACCTOCAOAATAAOCACCOOCTAACTACO TOCCAOCAOCCOCOO 404

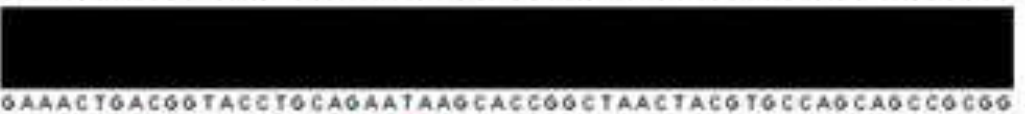

579 TAATACPR AGOQTOCAAG COTTRATCOOAATTAOTGQOCOTAAAOCGTOCGOAGGC ES WO TAATACHTAOOOTOCAAOCOTTGATCOGAATTACTOOOCOTAAAGCOTOCOCAOOC SSO

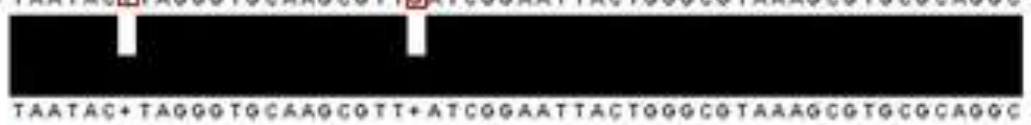

TAATACATAGOOTOCKAOCOTT A ATCOGAATTACTOOOCOTAAAGCOTOCOCAOCG

604 DPTTCOOAAA

S51 $\triangle D T+C O O A A A$

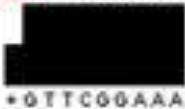

043

500

-OTTCQOAAA

Fig 7. Single nucleotide polymorphism (SNPs) showed 14 SNPs between the obtained isolate, and the nearest one on NCBI data base, AJ880396.1 based on pairwise alignment analysis method.

Annals of Agric. Sci., Moshtohor, Vol. 54 (1) 2016. 
Table 3. Evaluation of $A$. xylosoxidans as plant growth promoting rhizobacteria

\begin{tabular}{ccccc}
$\begin{array}{c}\text { IAA production } \\
\mu \mathrm{g} . \mathrm{ml}^{-1}\end{array}$ & $\begin{array}{c}\mathrm{GA} 3 \text { production } \\
\mu \mathrm{g} \cdot \mathrm{ml}^{-1}\end{array}$ & $\begin{array}{c}\text { Phosphate } \\
\text { solubilization } \\
\text { efficiency } \%\end{array}$ & $\begin{array}{c}\text { Phosphate } \\
\text { concentration } \mu \mathrm{g} . \\
\mathrm{ml}^{-1}\end{array}$ & $\begin{array}{c}\text { Nitrogenase activity } \\
\mu \mathrm{g} \mathrm{C} \mathrm{H}_{4} \cdot \mathrm{hr}_{\mathrm{L}} \mathrm{L}^{-1}\end{array}$ \\
\hline 55.3 & 12.46 & 112.5 & 25.4 & 60.43 \\
\hline
\end{tabular}

Effects of inoculation with $A$. xylosoxidans on tomato production

Effect of bio-inoculants on enzymes activity of tomato rhizosphere.

Soil enzymes activity has been suggested to be an index for soil fertility, whereas soil microbial activity has been used as an index of fertility. Data in Fig 8 showed that during the experimental periods, the effects of bio-inoculants (A. chroococcum and $A$. xylosoxidans) tended to be stronger on dehydrogenase, alkaline phosphatase and nitrogenase activities when compared with uninoculated treatment (Control). The overall data revealed that the inoculation with A. xylosoxidans had great effect on the previous soil enzymes activity compared with A. chroococcum EMCCN1458 inoculation. At flowering stage (60 DAT), inoculation with $A$. xylosoxidans showed about 4, 6 and 5 times increase in dehydrogenase, alkaline phosphatase and nitrogenase activities, respectively, when compared with initial period. While, control showed about two times increase in all enzymes activity.
Vegetative growth and yield characteristics

Inoculation of tomato with $A$. xylosoxidans affected $(\mathrm{p}<0.05)$ plant length, no. of branches.plant ${ }^{-}$ 1 , stems and leaves dry weight, root size and flower no. plant $^{-1}$ as compared to the control (Fig 9). Relative to A. chroococcum EMCCN1458 and the control, A. xylosoxidans strain caused $24 \%$ and $162 \%$ more fruits number plant $^{-1}$; for percentage fruit setting, it had more $12 \%$ and $35 \%$, respectively.

\section{Endogenous phytohormones content of tomato shoot.}

Levels of major tomato shoot endogenous phytohormones- both growth promoting and inhibiting ones- were all maintained at satisfactory concentrations $(\mathrm{p}<0.05)$ due to $A$. xylosoxidans inoculation . Relative to the Control shoots, concentrations of each of gibberellins (GA), auxins (IAA), and cytokinins were $79 \%, 226 \%$, and $177 \%$, respectively.

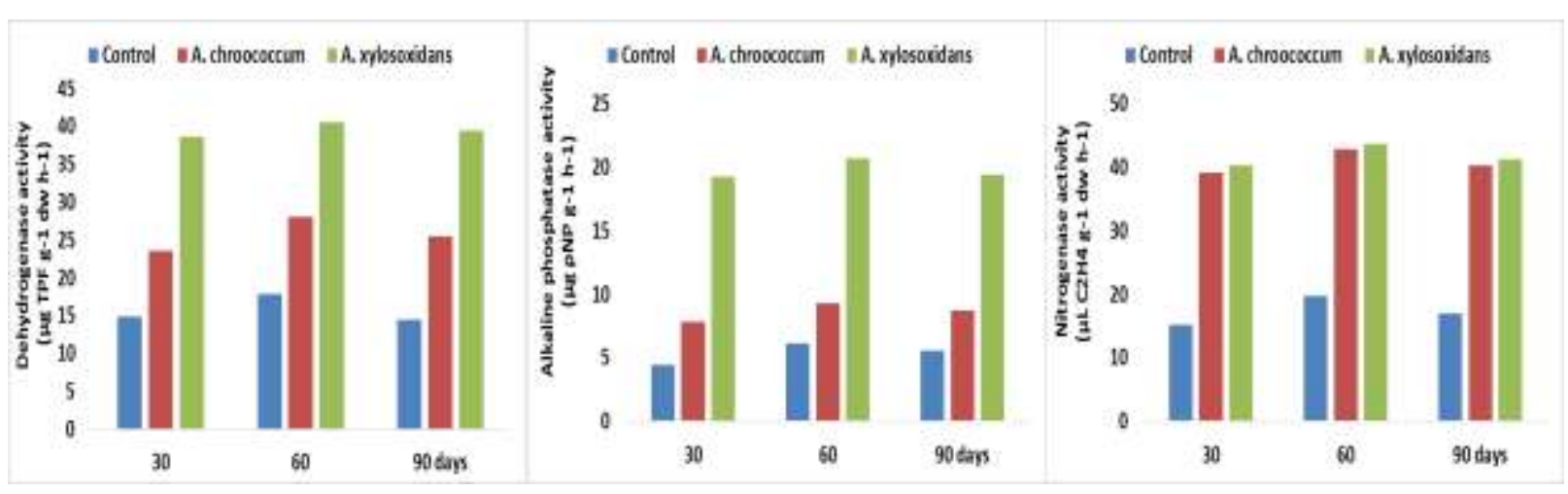

Fig 8. Effect of tomato inoculation with $A$. xylosoxidans on microbial enzymes activity.

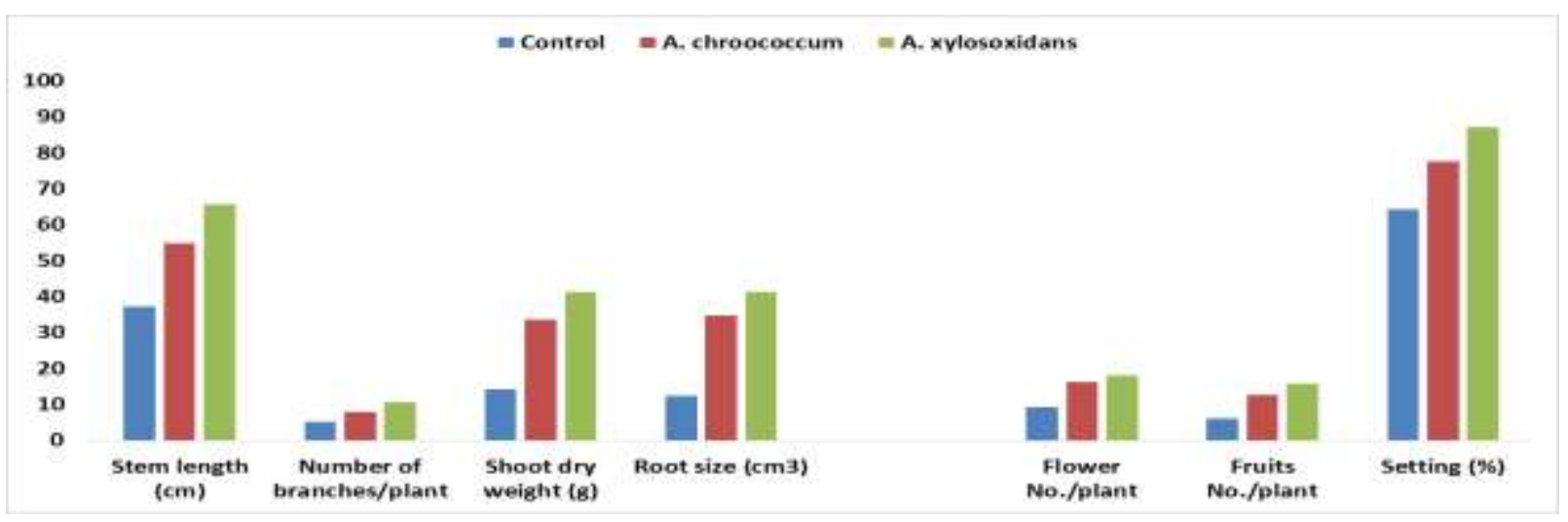

Fig 9. Vegetative growth and yield characteristics of tomato inoculated with A. xylosoxidans 
These concentrations dropped to differentials of $5 \%, 15 \%$, and $16 \%$, respectively, if compared to those resulted from A. chroococcum EMCCN1458 inoculant. For growth-inhibiting abscisic acid (ABA), the A. xylosoxidans inoculant caused comparative reductions of $51 \%$ and $18 \%$, respectively.

\section{Discussion}

Achromobacter xylosoxidans involved positively in different biotic activities in the soil which stimulate plant growth through mobilizing nutrients in soil and producing numerous plant growth regulators (Ahemad and Kibret, 2014). It is an aerobic, catalase, oxidase positive and Gramnegative bacilli that inhabits a variety of aqueous environments. Morphological and biochemical examination of the obtained isolate revealed several distinctive features related to genus Achromobacter. Our isolate was tested both morphologically and biochemically to provide definite information for using in bacterium identification. By using a light microscope, most cells were seen as typical rodshaped and gram-negative bacilli, but some of them apparently had curved forms. Moreover, bacterial cells were seen with a swollen at one end. So electron microscopy was used in addition to the previous methods to show bacteria in great detail in their natural environment. Electron micrographs revealed the accumulation of extracellular material on many of the cells often at one pole. Apparently these accumulations added irregular contours to the cell, and therefore in Gram stain, appear as curved and hooked forms which supported by Chester and Cooper (1979) findings. Achromobacter isolate was the exceedingly small colonies produced at $24 \mathrm{~h}$ and the subsequent rapid increase in colony size after continued incubation due to the elaboration of large amounts of mucoid material. In the API 20NE test of A. xylosoxidans, it utilized D-glucose, D-xylose and D-gluconate as sole carbon sources and characteristically form acid from d-xylose.

Data of morphological and biochemical examination of the obtained isolate agree with previous findings (Hugh 1970; Chester and Cooper, 1979; Kersters and De Ley 1984; Yabuuchi et al. 1998). They reported that the genus Achromobacter is a gram-negative, oxidase-positive, obligate aerobic, nonfermenting bacilli with peritrichous flagella, and is able to oxidize maltose, mannitol, and sucrose. Although, the biochemical studies using API 20NE revealed core of reactions useful in the identification of Achromobacter; however, they were not enough to fully identify the isolated strain.

Regarding, antibiograms of Achromobacter strain, previous studies by Knippschild et al (1996) and Gomez-Cerezo et al (2003) reported that $A$. xylosoxidans isolates were susceptible to piperacillin
(95.6\%), ceftazidime (91.1\%), imipenem (97.2\%) and trimethoprim-sulfamethoxazole $(78.6 \%)$ and resistant to aminoglycosides, ampicillin, aztreonam and most cephalosporins. The above-mentioned results are not in harmony with the obtained results except the susceptibility to imipenem. This is evident from the fact that the obtained isolate is a novice strain.

For confirming the isolate identification, sequencing of ribosomal genes is more reliable identification approach concerning non-fermenting Gram-negative rods than traditional phenotypic methods (Wellinghausen et al. 2006; Van Hal et al. 2008). In the current study, sequencing analysis results confirmed that the obtained bacterial strain has similar characteristics to those of A. xylosedanse. Based on the sequence of 16S rRNA gene, it was monitored at an accurate position of phylogenetic tree. This gene has been proven to have quite slow rates of evolution, indicating its genetic stability. An indication of this gene stability was confirmed by the GC content and of its slow evolutionary rate by the presence of only 14 SNPs. In this respect, many studies were conducted using $16 \mathrm{~S}$ rRNA gene method for identification and characterization of unknown bacterial isolates specially Achromobacter spp (Das et al. 2014; Srinivasan et al. 2015; Alhamlan et al. 2015).

One prominent feature of A. xylosoxidans noticed in this study is the ability to reduce atmospheric nitrogen molecule into ammonia (diazotroph) that was confirmed by estimating nitrogenase activity. Apart of diazotrophy, other beneficial characteristics such as IAA production and solubilized high amount of phosphate. The presence of growth promoting characters has been reported from many endophytic diazotrophic bacteria, including Acetobacter, Alcaligenes, Azospirillum, Enterobacter, Pseudomonas, and A. xylosoxidans. (Dawwam et al., 2013 and Wedhastri et al. 2014).

Obtained results are in agreement with the above reports but are novel especially for the bacterium $A$. xylosoxidans in the sense that it has been isolated from aquatic environment and able to produce GA3.

Application of $A$. xylosoxidans as a PGPR strain with tomato had great effect on microbial community and their activities especially their extracellular enzymes. These extracellular enzymes play an important role in soil biogeochemical cycles of $\mathrm{C}, \mathrm{N}$, and $\mathrm{P}$ that are involved in nutrient transformation (Burns and Dick 2002). Therefore, significant reductions in both soil enzymatic activity and soil microbial biomass should be considered as indicators of soil quality and land use impacts (Mganga et al. 2015). The importance of soil inoculation with PGPR strains and their role for increasing the activities of soil enzymes especially the distinctive role of the isolated A. xylosoxidans in this respect. This result may be attributed to the role of intercellular 
substances of $A$. xylosoxidans (i,e. plant growthpromoting substances and microbial enzymes) in promoting soil microbial proliferation and their activity. Moreover, the effect of boost inoculation of PGPR in supporting its colonization on plant root.

The encouraged growth of inoculated plants with A. xylosoxidans more than A. chroococcum EMCCN1458 may be attributed to the vital role of this strain in improving the availability and acquisition of nutrients such as phosphorus. Phosphate solubilizing microorganism is yet another important free-living soil microbiota that provide major nutrient especially $\mathrm{P}$ to plants under $\mathrm{P}$ deficient soils and enhance the overall growth and development of plants (Khan et al., 2014). Moreover, the application of diazotrophic endophytic bacteria appear to provide more of fixed nitrogen as compared to rhizospheric bacteria because the interior of plants is a more suitable riche for nitrogen fixation in view of low partial oxygen pressure (pO2) and direct accessibility of the fixed nitrogen to the plants (Prabhat and Kumar 2009).

Furthermore, A. xylosoxidans could produce IAA and GA3 that increase the surface area per unit of root length and were responsible for root hair branching with an eventual increase in acquisition of nutrients from the soil. These results are in harmony with (Zaidi et al 2009) who reported that various plants require different phytohormones, for example, IAA gibberellins and cytokinin for root morphogenesis and shoot development. The IAA affects the root development, tissue differentiation, and responses to light and gravity. Roots with larger surface area absorb more water and nutrients from the soils and translocate them to various organs of the plants resulting in profound growth and high yielding biomass and grain production. Gibberellins on the other hand, influence seed germination, stem elongation and development, flowering, and fruit setting of plants.

Generally, inoculation with A. xylosoxidans gave the highest value of promoting phytohormones level. Also, increment of endogenous hormones in tomato obtained in the present study may refer to the improvement of growth features. For example, increasing cytokinins could be in favor of increasing the number of formed branches and that could also increase transverse growth on the account of longitudinal one. Increasing of endogenous promoting phytohormones content of tomato shoot in case of inoculation with A. xylosoxidans may be due to the beneficial effect of strains in the production of PGPs.

Moreover, the proportions of total promoters to the inhibitor abscisic acid were relatively higher in case of A. xylosoxidans inoculation. Simulative effects of these treatments enhance the internal metabolically features such as promoting hormones of tomato towards maximizing its growth. This result is in agreement with that obtained by (Hosseny and
Ahmed, 2009; Abd El-Aal and Abd El-Rahman, 2014) who reported that maximizing growth and productivity of lettuce and sweet ananas melon were related to high promoting hormones content.

\section{Conclusion}

In view of the obtained results, it could be concluded that both integrated traditional and molecular characterization approaches for obtaining new friendly diazotrophic bacterial strains from an agricultural canal. The obtained isolate may be exploited as plant growth promoting rhizobacteria for various crops since it exhibited reasonable potential characteristics. Yet, its performance needs further assessment relative to many other growth-promoting rhizobacterial strains which have been in use. In addition, future strain studies should be implemented under field conditions in factorial combinations with other relevant dependent factors.

Moreover, it could be recommended that developing countries should be interesting the use of PGPR especially new effective rhizobacteria such as A. xylosoxidans to promote plant growth that increase crop production, decrease production costs and reduce environmental pollution. Taking into account this fact as well as other attributes of PGPR new strains, further investigations are continuing.

\section{References}

Abd El-Aal MM, Abd El-Rahman HM 2014. Impact of PGPR and inorganic fertilization on growth and productivity of sweet Ananas Melon. International Journal of Agricultural Science and Research (IJASR), 4(3):11- 26.

Abd El-Azeem SAM, 2007. Some plant growth promoting traits of rhizobacteria isolated from Suez Canal region, Egypt. African Crop Science Conference Proceedings Vol.(8):1517-1525

Ahemad M.; Kibret M., 2014. Mechanisms and applications of plant growth promoting rhizobacteria: current prespective. Journal of King Saud University- science, 26:1-20.

Alhamlan F S, Al-Qahtani A A, Al-Ahdal M N, 2015. Recommended advanced techniques for waterborne pathogen detection in developing countries. J. Infect. Dev. Ctries 9:128-135. doi: $10.3855 /$ jidc. 6101

Aneja KR., 2003. Experiments in Microbiology Plant Pathology and Biotechnology, Fourth Edition, New Age International (P) Ltd., Publishers, New Delhi; pp 320.

Bertrand H, Nalin R, Bally R, Marel JCC., 2001. Isolation and identification of the most efficient plant growth promoting bacteria associated with canola. Biol. Fert. Soil 33: 152-156.

Birnboim HC, Doly J, 1979. A rapid alkaline extraction procedure for screening recombinant plasmid DNA. Nucleic Acids Res 7: 1513-23.

Burns R G and Dick R P., 2002. Enzymes in the environment-activity, ecology, and application. 
Marcel Dekker, Inc.

Chester B.; Cooper L. H., 1979. Achromobacter Species: Morphological and Biochemical Characterization. Journal of Clinical Microbiology, Vol. 9, No. 3, p. 425-436.

Das S, Dash H R, Mangwani N, Chakraborty J, Kumari S., 2014. Understanding molecular identification and polyphasic taxonomic approaches for genetic relatedness and phylogenetic relationships of microorganisms. Journal of Microbiological Methods 103: 80-100.

Dawwam GE, Elbeltagy A, Emara HM, Abbas IH and Hassan MM., 2013. Beneficial effect of plant growth promoting bacteria isolated from the roots of potato plant. Ann. Agric. Sci. 58:195-201.

Diloworth MJ., 1970. The acetylene reduction method for measuring biological nitrogen fixation. Rhizobium News Letters, 15(7): p 155.

Dobbelaere, S., Vanderleyden, J., and Okon, Y., 2003. Plant growth-promoting effects of diazotrophs in the rhizosphere, Crit. Rev. Plant Sci. 22:107-149.

Ding, Y.; J. Wang; Y. Liu and S. Chen, 2005. Isolation and identification of nitrogen-fixing bacilli from plant rhizospheres in Beijing region. J. Appl. Microbiol., 99: 1271-1281.

Duncan DB. 1955. "Multiple range and multiple F tests".Biometrics11: 1-42.

Gomez KA, Gomez AA. 1984. Statistical Procedures for Agricultural Research. John Wiley $\&$ Sons, New York.

Gomez-Cerezo J, Suarez I, Rios JJ, Pena P, Garcia de Miguel MJ, de Jose M, 2003. Achromobacter xylosoxidans bacteremia: a 10year analysis of 54 cases. Eur J ClinMicrobiol Infect Dis; 22:360-3.

Gomila M, Prince-Manzano C, Svensson-Stadler L, Busquets A, Erhard M, Martínez DL, Lalucat J, Moore ERB., 2014. Genotypic and Phenotypic Applications for the Differentiation and Species-Level Identification of Achromobacter for Clinical Diagnoses. PLoSOne Published: December 4, 2014 DOI: 10.1371/journal.pone.0114356

Hosseny M H and Ahmed M MM., 2009. Effect of nitrogen, organic and PGPR on productivity of lettuce (CV. Romaine) in sandy soil under Assuit conditions. Ass. Univ. Bull. Environ. Res. 12 (1): $79-93$

Hugh R., 1970. A practical approach to the identification of certain nonfermentative gram negative rods encountered in clinical specimens. J. Conf. Public Health Lab 33:81-103.

Hunter RC, Beveridge T J., 2005. High-Resolution Visualization of Pseudomonas aeruginosa PAO1 Biofilms by Freeze-Substitution Transmission Electron Microscopy. Journal of Bacteriology 187: 7619-7630.

Inoue H, Nojima H, Okayama H., 1990. High efficiency transformation of Escherichia coli with plasmids, Gene 96: 23-28.

Jakobsen TH, Hansen MA, Jensen PO, Hansen L, Riber L, Cockburn API, Kolpen M, Hansen CR, Ridderberg W, Eickhardt-Sørensen SR, et al. 2013. Complete genome sequence of the cystic fibrosis pathogen Achromobacter xylosoxidans NH44784-1996 complies with important pathogenic phenotypes. PLOS One 8(7): e68484.

Jiang H, Dong H, Zhang G, Yu B, Chapman L R, Fields MW., 2006. Microbial Diversity in Water and Sediment of Lake Chaka, an Athalassohaline Lake in Northwestern China. Applied and Environmental Microbiology 72: 3832-3845.

Kersters K, De Ley J., 1984. Genus III. Agrobacterium Conn 1942. In Bergey's Manual of Systematic Bacteriology, vol. 1, pp. 244-254. Edited by N. R. Krieg \& J. G. Holt. Baltimore: Williams \& Wilkins. Moore, L. W., Bouzar, H

Khan, M.S., Zaidi, A., Ahmad, E., 2014. Mechanism of phosphate solubilization andphysiological functions of phosphate solubilizing microorganisms. In:Phosphate Solubilising Microorganisms: Principles and Application of Microphos Technology. SpringerVerlag, Switzerland, pp. 31-62.

Knippschild M, Schmid EN, Uppenkamp M, Konig E, Meusers P, Brittinger G, 1996. Infection by Alcaligenes xylosoxidans subsp. xylosoxidans in neutropenic patients. Oncology; 53:258-62.

Koshioka M, Harda J, Noma M, Sassa T, Ogiama K, Taylor J S, Rood S B, Legge $R \mathbf{L}$ and Pharis R P., 1983. Reversed phase C18 high performance liquid chromatography of acidic and conjugated gibbberellins. J. Chromatgr., 256:101115.

Krishnaraj, P. U., Dahale, S., 2014. Mineral Phosphate Solubilization: Concepts and Prospects in Sustainable Agriculture. Proc Indian Natn Sci Acad 80 No. 2, Spl. Sec. pp. 389-405

Matuschek E, Brown DFJ, Kahlmeter G., 2014. Development of the EUCAST disk diffusion antimicrobial susceptibility testing method and its implementation in routine microbiology laboratories. Clin. Microbiol. Infect 20: O255O266.

Mganga K Z, Razavi B S and Kuzyakov Y., 2015. Microbial and enzymes response to nutrient additions in soils of Mt. Kilimanjaro region depending on land use. European Journal of Soil Biology 69: 33-40.

Nautiyal CS., 1999. An efficient microbiological growth medium for screening phosphate solubilising microorganisms. FEMS Microbiol. Lett. 170: 265-270.

Nguyen C, Yan W, Le TF., 1992. Genetic variability phosphatesolubilizing activity of the ectomycorrhizal fungus Laccaria bicolor (Maire) P.D. Orton. Plant Soil. 143:193-199. 
Nicander B, Stahl U, Bjorkman $P$ and Tillberg E., 1993. Immyno affinity co-purification of cytokinins and analysis by high-performance liquid chromatography with ultra violet spectrum deterction. planta, 189: 312-320.

Okafor N, MacRae IC., 1973. The influence ofmoisture level, light, aeration and glucose uponacetylene reduction by a black earth soil. Soil Biol.Biochem., 5, 181 - 186.

Pandya ND and Desai PV., 2014. Screening and characterization of GA3 producing Pseudomonas monteilii and its impact on plant growth promotion. Int. J. Curr. Microbiol. App. Sci. 3: 110-115.

Prabhat Jha, , Kumar A., 2009. Characterization of Novel Plant Growth Promoting Endophytic Bacterium Achromobacter xylosoxidans from Wheat Plant. Microb. Ecol 58:179-188.

Sarwart M, Arshad M, Matens DA, Frankenberger WT., 1992.Tryptophandependent biosynthesis of auxins in soil. Plant Soil. 147: 207-215.

Schinner F, Oehlinger R, Kandeler E, and Margesin R., 1996. Methods in Soil Biology.Springer Lab Manuals, Part I. pp 213, 241.

Sivasakthi S., Usharani G., Saranraj P., 2014. Biocontrol potentiality of plant growth promoting bacteria (PGPR) - Pseudomonas fluorescens and Bacillus subtilis: A review. Afr. J. Agric. Res. Vol. 9(16), pp. 1265-1277, 17 April.

Spilker T, VanDamme P, Lipuma JJ., 2013. Identification and distribution of Achromobacter species in cystic fibrosis. J. Cyst. Fibros 12:298301.

Srinivasan R, Karaoz U, Volegova M, MacKichan J, Kato-Maeda $M$, Miller S, Nadarajan $R$, Brodie E L, Lynch S V., 2015. Use of $16 S r R N A$ Gene for Identification of a Broad Range of Clinically Relevant Bacterial Pathogens, PLOS ONE, DOI:10.1371/journal.pone 0117617, 1-22.

Vacheron J., Desbrosses G., Marie-Lara B., Touraine B., Moënne-Loccoz Y., Muller D., Legendre L., Wisniewski-Dyé F.,.PrigentCombaret C., 2013. Plant growth-promoting rhizobacteria and root system functioning. Front Plant Sci. 2013; 4: 356. doi: 10.3389/fpls.2013.00356

Van Hal S, Stark D, Marriott D, Harkness J., 2008. Achromobacter xylosoxidans subsp. xylosoxidans prosthetic aortic valve infective endocarditis and aortic root abscesses. J. Med. Microbiol 57: 525-527.

Vincze T, Posfai J and Roberts RJ., 2003. NEBcutter: a program to cleave DNA with restriction enzymes Nucleic Acids Res. 31: 36883691

Wayne LG, Brenner DJ, Colwell RR., 1987. Report of the ad hoc committee on reconciliation of approaches to bacterial systematics. Int. J.
Syst. Bacteriol 37: 463-4.

Wedhastri S, Fardhani DM, Kabirun S, Widada J, Widianto D, Evizal R, Prijambada ID., 2014. Legume Nodulating Bacterium, Achromobacter xylosoxidans Found in Tropical Shrub Agroecosystem, Sumatera, Indonesia. Indones. J. Biotechnol 18.

Wellinghausen N, Wirths B, Poppert S., 2006. Fluorescence in situ hybridization for rapid identification of Achromobacter xylosoxidans and Alcaligenesfaecalis recovered from cystic fibrosis patients. J ClinMicrobiol 44: 3415-3417.

Wittmann J, Dreiseikelmann B, Rohde C, Rohde M, Sikorski J., 2014. Isolation and characterization of numerous novel phages targeting diverse strains of the ubiquitous and opportunistic pathogen Achromobacter xylosoxidans, Plos ONE, 9(1):e86935. doi:10.1371/journal.pone.0086935.

Yabuuchi E, Kawamura Y, Kosako Y, Ezaki T., 1998. Emendation of the genus Achromobacter and Achromobacter xylosoxidans and proposal of Achromobacter ruhlandii nov., Achromobacter piechaudii (Kiredjian et al.) comb. nov., and Achromobacter xylosoxidans subsp. denitrificans (Ruger and Tan) comb. nov.MicrobiolImmunol 42: 429-438.

Zaidi A, Khan MS, Ahemad M, Oves M., 2009. Plant growth promotion by phosphate solubilizing bacteria. Acta Microbiol Immunol Hung 56: 263-284. 


\section{الدور المحتمل للسلالة الجديدة Achromobacter xylosoxidans كعامل مشجع لنمو النبات}

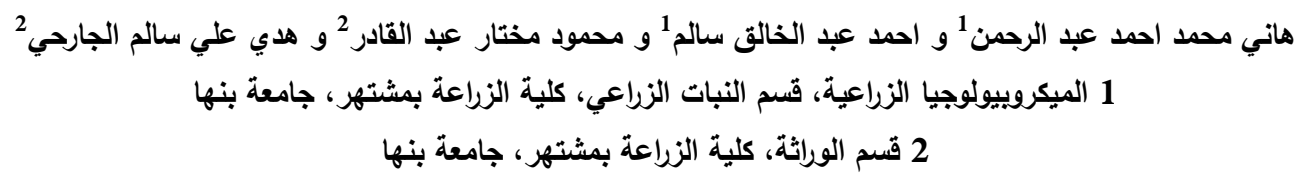

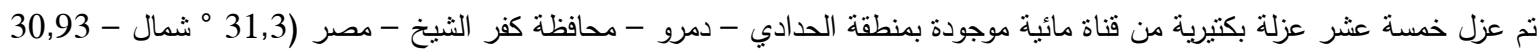
• شرق). تم العزل علي بيئة أثنبي الخالية من النيتروجين. أما عملية المفاضلة بين العزلات فتم إجرائها علي اساس تقدير نشاط إنزيم النيتروجينيز

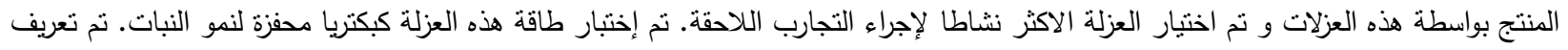

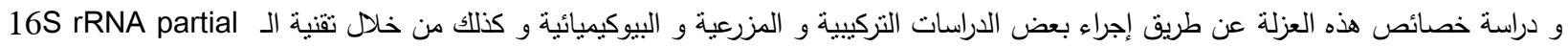
sequence التي اظهرت نسبة تقارب تعادل 97\% مع السلالة Achromobacter xylosoxidans, AJ880396.1 . تبين قدرة هذه السلالة علي

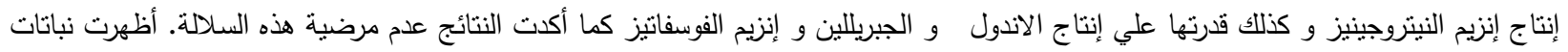

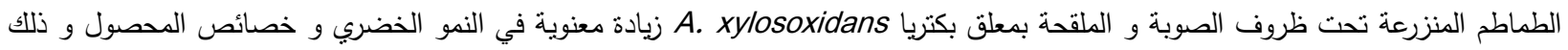
A. Anد المقارنة بالنباتات الملقحة بيكتريا xylosoxidans, 